\title{
CORRUPTION AND NICCOLO MACHIAVELLI
}

\author{
Tomy Michael \\ Faculty of Law \\ University of 17 Agustus 1945 Surabaya
}

\author{
ARTICLE INFORMATION \\ Article history: \\ Received August01, 2015 \\ Revised November14, 2015 \\ Accepted April 15, 2016

\section{JEL Classifications} \\ K42
}

\section{Key Words:}

Corruption,

Niccolo Machiavelli,

Leaders.

\section{DOI:}

10.21532/apfj.001.16.01.02.21

\begin{abstract}
The increasing corruption in Indonesia occurs because of the indecision of the leader. This is contrary to the 1945 Constitution of the republic of Indonesia that the position of the president is the chief executive. This has repercussions on the position where the president to act without pressure in combating corruption. The leader can apply the Niccolo Machiavelli's idea that is to take the ideas of the people and focus on those ideas, and then restore those ideas to the people so that they apply them, and to make corrections in case of errors. Such is the basic method of leadership. In conclusion, Niccolo Machiavelli's ideais appropriate to be applied in combating corruption because in the Law Bo. 20 of 2001 has created a justice for the perpetrators of corruption when declared as the accused of corruption. The main concern is to take advantage with the position of president as the chief executive, in which the president may also be subject to the decisive law. This firm attitude will have an impact on law enforcement to implement legislation fairly. The suggestions that can be put forward in combating corruption is understanding the doctrine of jurisprudence, from countries, that are considered poor should be a critical review in the development of legal science in Indonesia, extending the meaning of gratification by incorporating sexual elements, and applying social sanctions.
\end{abstract}

\section{Keywords:}

\section{INTRODUCTION}

In the study of jurisprudence, ${ }^{1}$ it is very necessary to pay attention to the existence of nation state. Nation state can be defined as a modern format in which the recognized state authority regulates the whole nation or ethnic groups

1 The study of the actions or deeds relating to the norms and principles of law, in Peter Mahmud Marzuki, 2008, Pengantar Ilmu Hukum, Jakarta: Kencana Prenada Media Group, p. 10. 
existing in its territory. The nation state unites the different regions and its people into a new government territory. The nation state forms a new political unity and a new national unity. The binding spirit is national spirit, and such spirit is known as nationalism. ${ }^{2}$ But in reality, the unity of the Indonesian nation is torn apart by corruption, which means that corruption is as an argument in the new political unity so that the unity of the nation is experiencing a change of the nature of its individual. Individual attitude means that when the perpetrator of corruption becomes the suspect, there will be pros and cons action in providing assessment. Humans have ability to think, freedom to choose and ability to make decision. The political consequence of individualism is the independence of the country whose citizens have rights in law and politics embodied in the rule of law. ${ }^{3}$ So it appears the pros action, which means that there is unwritten justification in a group, and the cons action, which means to reject all forms of corruption. Thus corruption still continues to grow in Indonesia because of the absence of unified voice in its eradication.

The ways to eradicate corruption in Indonesia just view the quality of legal subject that is considered as the suspect of corruption. The quality of legal subject affects the handling of the matter, which means that when the legal subject is close to the elements of power, it would be reluctance to complete it. In this case,

2 Winarno, 2013, Paradigma Baru Pendidikan Kewarganegaraan, Jakarta: PT Bumi Aksara, p. 18-19.

3 Surya Prakash Sinha, 1993, Jurisprudence: Legal Philosophy in A Nutshell, St Paul Minnesota: West Publishing, p. 11. the writer rejects the idea of Lord Acton John Emerich Edward Dalberg-Acton as the content of his letter addressed to Bishop Mandell Creighton (1887) that "power tends to corrupt, and absolute power corrupts absolutely. Great men are almost always bad men." Changes in leadership principle are the best way out.

\section{DISCUSSION}

\section{A. Arguments in choosing the figure of Niccolo Machiavelli}

In this paper, the writer refers to violence or attitude desired by Niccolo Machiavelli. It can be described when there is a question "is loved better than feared, or feared better than loved?" The question might be able to be answered that one should expect both of them, but since it is difficult to bring both of them together in one person, it is much safer to be feared than to be loved when both of themmust be channeled. These elements must exist in humans in general, in which people tend to be ungrateful, fickle, false, coward, and covetous. When you are successful, such characters will be entirely yours. ${ }^{4}$ In the book entitled "The Prince", it is described the basic values of the leadership of a leader where he must keep giving priority to the truth. If the leader cannot be a respected figure as well as to be loved, it would be better if he is only respected by his people in upholding his principles.

4 Niccolo Machiavelli born on May 3, 1469, in Florence. He was the second son of Bernardo de Nicolo Machiavelli who was a reputableAdvocates. The writer refers to Niccolo Machiavelli, 2012, The Prince, United States: The Project Gutenberg. And also compared with Niccolo Machiavelli, Sang Pangeran, 2014, Jakarta: PT Gramedia, hal. 158. 


\section{B. The Position of President in Indonesia}

Before entering the discussion on corruption eradication, it is better to discuss the nature of the president in the Republic Indonesia. The word "president" is derived from "presides" which is a derivation of the Latin word "prae - before" and "sedere - sit" absorbed into "praeses". The word "praeses" means: 1. Roman law, a governor of a province; 2.The president of a college or university. ${ }^{5}$ The word president can also be interpreted as "the chief political executive of a government; the head of state, the chief executive officer of a corporation or other organization". ${ }^{6}$ Meanwhile, the word "president" normatively cannot be interpreted rigidly because the legislations give different meanings depending on the intended text.

The legislation based on Article 7 paragraph (1) of the Law of the Republic of Indonesia No. 12 of 2011 on the Establishment of Legislation (Law No. 12 of 2011) confirms that the sequence of the legislation is the 1945 Constitution of the Republic of Indonesia (UUD NRI 1945); the Decree of the People's Consultative Assembly (MPR); Government Regulation in Lieu of Law; Government Regulations; Presidential Decree; Provincial Regulation; and Regulation of the District / City. There are additional types of legislation in accordance with Article 8 of Law No. 12 of 2011 which include regulations set by the People Consultative Assembly (MPR), the House of Representatives (DPR), the Regional

5 Bryan A Garner, 2009,Black's Law Dictionary, Ninth Edition, United States of America: Thomson Reuters, p. 1294.

6 Bryan A Garner, 2009,Black's Law Dictionary, Ninth Edition, United States of America: Thomson Reuters, p. 1304
Representatives Council (DPD), the Supreme Court (MA), the Constitutional Court (MK), the Supreme Audit Agency (BPK), the Judicial Commission (KY), Bank Indonesia (BI), the Minister, board, agency, or commission level established by law or government at the behest of the Law, the Provincial House of Representatives (DPRD Prov.), the Governor, the House of Representatives District / City ( DPRD Kab. / Kota), Regent / Mayor, Village Head or its equivalent.

In the paradigm of (the achievement of a group from the previous group in which the latest achievement compares the way how to conduct scientific activities and the achievement is quite open so that all sorts of issues are submitted to the practicing group reassigned to be solved) ${ }^{7}$ national and state constitutional in Indonesia, the implementation of people's sovereignty in the life of the nation and the state is in conformity with the 1945 Constitution. ${ }^{8}$ However, the writer states that it is not so because in Indonesia, the president still serves as the head of government and head of state.

The president has a different function and position before the amendment of 1945 Constitution:

1. The Position of President in the time of1945 Constitution

7 Thomas S Khun, 2012, Peran Paradigma Dalam Revolusi Sains, Bandung: Remaja Rosdakarya, p. 10.

8 Sri Soemantri M, 1996, Penerapan Kedaulatan Rakyat Dalam Kehidupan Bernegara Berdasarkan Pancasila Dan Undang-Undang Dasar 1945, Bandung: Citra Aditya Bakti, p. 435. 
a. The president's power in the field of executive

The president's power in the field of executive can be found in Article 4 paragraph (1) and Article 5 paragraph (2) of the 1945 Constitution. The president's power in running the government is limited by the Constitution so that the president cannot make deviation. In this time, the Republic of Indonesia adheres to the constitutional system (in the explanations of 1945 Constitution), the government which is based on constitutional system (basic law), not absolutism.

In carrying out his administration, the president is assisted by state ministers (Article 17 paragraph (1) of the 1945 Constitution) and the responsibility remains in the hands of the president. On the other hand, ministers are appointed and dismissed by the President (Article 17 paragraph (2) of the 1945 Constitution). Because the president is responsible for all administration, the president will direct the actions of ministers in order to conform to his will. Article 17 paragraph (2) of the 1945 Constitution can also be interpreted that the ministers are not responsible to Parliament for their appointment is not dependent on the support of Parliament as in the case with in the parliamentary system.

Referring to Article 4 (2) of the 1945 Constitution, the president is assisted by a vice president in carrying out his duties. Soepomo, as the chairman of the Small Committee of the Designer of Constitution said in the big meeting of the Preparatory Committee for Indonesian Independence (BPKI) on July
15, 1945. "The president, in his daily work running his obligations, is assisted by two vicepresidents who have a very high position and do not depend on the president because they are appointed by the People's Consultative Assembly “. 9

According to Wirjono Prodjodikoro, the word "assisted" in Article 4 Paragraph (2) of the 1945 Constitution indicates that the vice president will act as the first person when the president is absent (this is reinforced in Article 8 of the 1945 Constitution). It can be deduced that the position of vice president, as the assistant to the president, is under the president, and the vice president is not appointed by the president but by the Assembly.

b. The President's power in the field of Legislative

The provisions of the 1945 Constitution which state that the president has the authority in the field of legislative are:

a. Article 5 (1) of the 1945 Constitution "The president holds the power to make laws with the approval of the Parliament"

b. Article 20 (1) of the 1945 Constitution, "Every law requires the approval of Parliament"

c. Article 21 paragraph (1) of the 1945 Constitution "Members of Parliament are entitled to submit draft bill"

In the case of force, the president has the right to set the Government Regulation in Lieu of Law (Article 22 paragraph (1) of the 1945

9 Moh Kusnardi dan Harmaily Ibrahim, 1986, Pengantar Hukum Tata Negara Indonesia, Jakarta: Pusat Studi HTN Fakultas Hukum UI, p. 200. 
Constitution). The formation of Government Regulation in Lieu of Law (Perppu) shall get approval from the Parliament in the next session (Article 22 paragraph (2) of the 1945 Constitution), it is aimed to fulfill the principles of democracy and prevent arbitrary power from the government because every government policy related to the interests of the people can be justified, and if the Parliament does not give approval, the regulation has to be removed (Article 22 paragraph (3) of the 1945 Constitution).

c. The President's Power as the Head of State

The president as the Head of state is set in

1. Article 10 of the 1945 Constitution "The President holds the highest authority of the Army, Navy and Air Force"

2. Article 11 of the 1945 Constitution "The President with the approval of Parliament declares war, makes peace and agreements with other countries"

3. Article 12 of the 1945 Constitution "The President declares a state of emergency. The terms and results of the state of emergency are stipulated by law"

4. Article 13 paragraph (1) of the 1945 Constitution "The President appoints ambassadors and consuls"

5. Article 13 paragraph (2) of the 1945 Constitution "The President accepts ambassadors of other countries"

6. Article 14 of the 1945 Constitution "The President gives clemency, amnesty, abolition and rehabilitation"
7. Article 15 of the 1945 Constitution "The President gives the title, honors, and other marks of honor"

\section{The position of President in the time} ofthe Constitution of the Republicof the UnitedStates of Indonesia (RIS)

In this period, Indonesia adopted parliamentary government of English pattern as a result of negotiations and agreement of the Round Table Conference in The Hague, Netherlands on December 27, 1949, attended by the Indonesian delegation, the delegation of federal affairs consultative committees and the delegation of the Kingdom of the Netherlands, and witnessed by United Nations Commission for Indonesia (UNCI) as the representatives of the United Nations. The prevailing Constitution was then the Constitution of the Republic of the United States of Indonesia (RIS). In accordance with Article 69 paragraph (1) of the Constitution of the Republic of the United States of Indonesia (RIS), the position of the president is as the head of state, while the government is the president and ministers (Article 68 paragraph (1) of the Constitution of RIS.

\section{The position of President in the time of the} 1950 Interim Constitution (UUDS 1950)

In this period, through Article 90 of the Constitution of the Republic of the United States of Indonesia (RIS), there was amendment to the Constitution of RIS by changing the parts fromstate of the union to unitary state. This was done through the Federal Law No. 7 of 1950, 
in other words, the Interim Constitution, in its form, is the changes of the Interim Constitution of RIS. ${ }^{10}$

In the Interim Constitution does notexplicitly state what or who is meant by the government. However, when viewed the provisions set forth in Article 45 until Article 55 contained in Chapter II of Part I of the Interim Constitution, there are provisions concerning the president, vice president and minister or ministers. So the government is the president, vice president, minister or ministers. It is reinforced in Article 83 of the Interim Constitution that the president and vice president cannot be contested and the ministers are responsible for the whole of government policies either together for the whole or each of their own parts.

Referring to Article 84 of the Interim Constitution that the president can dissolve parliament if it is deemed no longer represent the will of the people. In 1955 the first General Election was held to establish Regional Parliament, Central Parliament and Constituent Assembly. The purpose of the establishment of Constituent Assembly is to determine the Constitution which replaces the Interim Constitution of 1950 . The voting that was attended by less than $2 / 3$ of the participants in the session resulted in the emergence of the Republic of Indonesia Presidential Decision No. 150 on the Decree (Decree July 5, 1959) containing the dissolution of the Constituent Assembly, the invalidity of 1950 Interim Constitution and the re-enactment of the 1945

10 Jazim Hamidi andMustafa Lutfi, 2010, Hukum Lembaga Kepresidenan Indonesia, Bandung: Alumni, p. 10.
Constitution.

4. The Position of President in the Period from 1966 to 1973

The first shift related to the presidency occurred in 1966, when Mr. Soekarno formally issued Order of March the Eleventh, better known as Supersemar 1966 to Ministry of the Army Commander (Gen. Soeharto). Formally, Supersemar is an ordinary constitutional measure considering the position of minister, that Army Commander is the assistant to the president within the meaning of Article 17 of the 1945 Constitution.

But at the time of the release of Supersemar (administratively), it immediately changed upon the release of TAP MPRS No.IX / MPRS / 1966 on Warrant of President / Commander in Chief of the Armed Forces / Great Leader of the Revolution / MPRS Mandatory, then Supersemar was no longer under the authority of the president. Even as the mandatory of MPRS, the president should be subject to the Supersemar. With the existence of TAP MPRSit was no longer accountable for his actions to the president but to MPRS because it changed its position into the Bearer of the Decree No. IX / MPRS / 1966. The existence of two people as the MPRS mandate holders who at the same time own presidential authority could only be resolved at the time of the issuance of Presidential Announcement / Mandatory MPRS dated February 20, 1967 on the Transfer of State Governmental Power to the Bearer of the Decree of MPRS No. IX / MPRS / 1966 which was then used as one of the considerations to re-withdraw the MPRS 
mandate from Soekarno including all the State Governmental Power set by the Constitution and appointed General Suharto as the Bearer of the Decree of MPRS No.IX / MPRS / 1966 as the president. In the explanation of the Decree No. XXXIII / MPRS / 1967, it is stated that "... the General Soeharto, as the Bearer of the Decree of MPRS No. IX / MPRS / 1966, is the President of the Republic of Indonesia “.

5. The Position of President in the time of 1945 Constitution after the Period of Change

In the time of the 1945 Constitution after the fourth amendment, the position of the president was as the chief executive because there were some state institutions which were abolished and it was established several new state institutions to meet the needs of national and state life. This could be seen in Article 1 (2) of the 1945 Constitution that sovereignty belongs to the people, and reinforced in Article 2 paragraph (1) that the membership of the Assembly is for the purpose of optimizing the implementation of the sovereignty of the people and that all members of the Assembly are elected by the people through elections and to increase the legitimacy of the Assembly. The amendment to Article 3 on the authority of the Assembly has an implication in the occurrence of a fundamental change in the state system in Indonesia, from MPR supremacy system to a system of counterbalance and Supervision. MPR no longer set the national guidelines and select and appoint the president and vice president.

\section{Paradigm of Corruption Eradication in Indonesia}

Nowadays, a different paradigm is found in the community that corruption always occurs due to weak legal system in a country and dominant power. This paradigm, when associated empirically in Indonesia, has actually occurred even before the era of reform. The weak legal system can be seen that the President as the head of state has a dominant power delegated by the 1945 Constitution, in which the 1945 Constitution is the basis for committing corruption. But currently, the condition is just the opposite, where corruption occurs not because of weak legal system and dominant power but the elements of education, the understanding of corruption and the institutions that handle corruption.

Understanding the complex corruption is needed to find out the main points of the problem. At present, there are canalization and extension related to the meanings the word "corruption". Corruption, in the context of action, is no longer regarded as something special but it has been transformed into an action that can be done by anyone. In addition, with the extension of the meaning related to the word "corruption", the right thing to do is to prevent its expansion using better legal systems (legal systems outside the box). ${ }^{11}$

In a scientific level, corruption is an extraordinary crime that requires extraordinary

11 Tomy Michael, Pemberantasan Gratifikasi Dengan Pendidikan, Mimbar Keadilan Januari Juni 2014, Surabaya: Laboratorium Ilmu Hukum - Fakultas Hukum Universitas 17 Agustus 1945 Surabaya, p. 62. 
Tomy Michael : Corruption and Niccolo Machiavelli..... Page 263-274

ways. This can be seen in the preamble of the Law of the Republic of Indonesia Number 20 of 2001 on the Amendment to Law Number 31 of 1999 on Eradication of Corruption (Law No. 20 of 2001) that corruption, that has been widespread, not only harm the state finance, but also a violation of the rights of the social and the economy of the society at large, so corruption needs to be categorized as a crime in which the eradication should be done in an extraordinary way. Quoting the explanation of Law No. 20 of 2001, the extraordinary way means to include that the application of inverted authentication system, that is the authentication charged to the defendant.

The phrase "inverted authentication system" should be replaced with a more appropriate phrase "reversal burden of proof / omkering van hewijslast". Quoting the opinion of Edwin H. Sutherland that:

"The criminal statistics show unequivocally that crime, as popularly conceived and officially measured, has a high incidence in the lower class and a low incidence in the upper class; less than two percent of the persons committed to prisons in a year belong to the upper class. These statistics refer to criminals handled by the police, the criminal and juvenile courts, and the prisons, and to such crimes as murder, assault, burglary, robbery, larceny, sex offences, and drunkenness; it does not include traffic violations. ${ }^{12}$

12 Gilbert Geis dan Robert F Meier, 1977, White Collar Crime; Offensen in Business, Politics, and The Professions, New York: The Fress Press, p. 38.
The idea of Edwin H. Shuterland implies that law enforcement against conventional crimes tend to attract the attention of law enforcers rather than the crimes involving subjects with high economic and social status. Of course, this idea shows that corruption has been under discussion in various scopes, but the handling is still not optimal.

In Indonesia, through the Decree of MPR No.XI/MPR/1998, on Corruption Eradication which replaced the Law of the Republic of Indonesia Number 3 of 1971 on Corruption Eradication explains that in its consideration contains a concentration of power, authority, and responsibility on the President / Mandatory of the People's Consultative Assembly of the Republic of Indonesia which resulted in the malfunction of the highest state institution and other high state institutions, and the lack of the development of community participation in providing social control in society, nation and state. This shows that Indonesia has the spirit of combating corruption.

A different opinion is expressed by Soerjono Soekanto that conceptually, the core and meaning of law enforcement lie in social life and there are several factors that influence the success of law enforcement itself - including its own legal factors; law enforcers factor that includes officers or agencies that create and implement the law; factor of supporting facilities of the law enforcement; community factor; cultural factor, as a result of creative works and a sense based on human and social life. Essentially, the understanding of the above definition is that law enforcement actually lies 
in the individual's own willingness to create a legal certainty in society. According to Hikmawanto, judicial independence is a key factor that determines the face of the law. And the judicial independence is determined by the model of the performance of judges. ${ }^{13}$

But in the paradigm of Anthon Freddy Susanto, it is said that the law, for a judge, is only unfinished text and not final text and this not only applies to the judge, but also to other law enforcement agencies and to government administrators. It makes the laws containing general and abstract legal norms cannot be applied appropriately. ${ }^{14}$

The operational details are further regulated by the government administration that know better how to implement the law as it should be. In various laws there is always the delegation of authority to further regulate something with governmental regulations or rules of the president.

Law is basically an open system, but in the legal system there are open system and closed system. Open system means that the

13 Hikmawanto, 2012, Quo Vadis Independensi Peradilan Indonesia, Surabaya: Visipress Media, hal 34.

14 Perlu dipahami bahwa peraturan perundangundangan tidak sekadar teks namun didalamnya dapat berupa penafsiran dan interpretasi.Hal ini dapat dilakukan dengan hermeneutika hukum, salah satunya dengan pemikiran Hans-Georg Gadamer bahwa secara umum pengalaman tentang ada dikebiri oleh teks. Apakah ia tidak menghasilkan makna atau maknanya tidak sesuai dengan apa yang kita harapkan. Inilah yang membuat kita memahami kemungkinan perbedaan di dalam penggunaannya, dalam HansGeorg Gadamer, 2010, Kebenaran Dan Metode, Yogyakarta: Pustaka Pelajar, p. 324. rules in the legal system open up the possibility for differences in the interpretation. Due to the differences in interpretation, the rules are always changing. ${ }^{15}$ According to Dworkin, as quoted by Anton Freddy Susanto, "if the law is an interpretive concept, any jurisprudence that is deemed worthy of being called science must be built on the basis of an interpretation". ${ }^{16}$ Meanwhile, Paul Scholten argues that the existing systematic interpretation lies in the law itself. ${ }^{17}$ The reason is that the rules are logically located and interconnected with each other, realizing unity. Then Anthon Freddy Susanto argued "... but the norm system itself remains open to interpretation. When the norm is made, there will be different from the norm that has been validated. And the norm that has been validated will be slightly different from the norm after being interpreted ". The desire to return to the formal meaning of the norm is usually serious disruption on how it is captured by the receiver of the norm.

In addition to the legal interpretation by scholars, the legal discovery by a judge can occur if there is a legal vacuum. How to qualify the laws to the certain concrete events is not always easy to find, because in practice the rule of law can be found written, but it is unclear, incomplete or even nonexistent.

Essentially, there is no perfect legislation. There must be shortage and limitation in it.

15 H Ansori, 2013, Gratifikasi Seksual Dalam Persona Korupsi, Surabaya: R.A.De.Rozarie, p. 43.

16 Anthon Freddy Susanto, 2005, Semiotika Hukum, Bandung, p. 152.

17 Paul Scholten, 2003, Struktur Ilmu Hukum, Bandung, p. 31. 
There is no truly complete or clear legislation to set the human activities. ${ }^{18}$ The legislation is static and rigid, while the development of human activities always increase over time, either the type or the amount, so it is understandable that later came an expression of "Het recht hink Achter de feiten ann", that the written law is always behind the event.

\section{Correlation between the Eradication of}

\section{Corruption in Indonesia and Niccolo}

\section{Machiavelli}

In "The Prince”, Niccolo Machiavelli said that "goodness plays an important role because it has become the nature of human not to be separated from all the goodness that have been given as the goodness that they have received". The idea which is based on this ecclesiastical law is a philosophical foundation that can be applied in Indonesia in eradicating corruption. This is also supported by four (4) main elements, namely:

1. Life because there are ancient religious laws (although the prince behaving badly)

2. Prince has a country and not keeping it

3. Prince has the people and not setting them

4. Although the state and the people are not kept, they all are peaceful and pleasant as enforced through the power of the Divine $(\mathrm{God})^{19}$

The Prince, in this element, is actually a model citizen. This principle is in line with what spoken by Socrates that each should represent:

\footnotetext{
18 Bambang Sutiyoso, 2006, Metode Penemuan Hukum, Yogyakarta: UII Press, p. 78.

19 Niccolo Machiavelli, 2014, Sang Pangeran, Jakarta: PT Gramedia, p.15.
}

1. The virtue of wisdom

2. Justice

3. Frugality

4. Courage $e^{20}$

The writer assumes that the president is actually required to do so because he, in the present government system in Indonesia, is the chief executive. Niccolo Machiavelli said that violence cannot be used as a way of imposing the will of the life of the nation. According to the book entitled "Indonesia Menggugat" it is said "where is the worldly power which could dampen the spirits of a nation, where is the worldly power which could hold something in searching for life", ${ }^{21}$

Niccolo Machiavelli also apply the ideal leader, in which it is more prudent if someone has a reputation as a violent man though censured but not hated instead of having the name as a usurper who will give birth to ridicule with hatred..$^{22}$ Niccolo Machiavelli's idea is in accordance with Article 1 (3) 1945 Constitution that Indonesia is a state of law. State of law can be categorized as "The principle of the Republican Government is virtue, and the means to be adopted during its establishment is terror". ${ }^{23}$

20 Platon, 2015, Xarmides (Tentang Keugaharian), Yogyakarta: PT Kanisius, p. 36.

21 Soekarno, Tanpa Tahun, Indonesia Menggugat Pidato Pembelaan Bung Karno Dimuka Hakim Kolonial, Djakarta: Pradnjaparamita III, hal 70.

22 Niccolo Machiavelli, 2014, Sang Pangeran, Jakarta: PT Gramedia, p.154.

23 Frédéric Bastiat, 2015, The Law, Surabaya: R.A.De.Rozarie, p. 51. 


\section{CONCLUSION AND SUGGESTION A. Conclusion}

Niccolo Machiavelli's idea is appropriate to be applied in eradicating corruption because in Law No. 20 of 2001 has created a justice for the people when the corruptor has been accused of committing corruption. But referring to the legal system theory by Lawrence M Friedman, in which the legal system is divided into structure, substance and culture, the writer considers that it is the legal culture that needs to get more attention.

The main concern is to take advantage with the president as the chief executive, so the president may be the assertive subject to laws. This assertive attitude will have an impact on the law enforcement to implement the legislation fairly.

\section{B. Suggestion}

The suggestions which can be put forward in combating corruption are:

1. The understanding of the doctrines of jurisprudence, from other countries, that are considered poor should be a critical review of the development of law in Indonesia. This is important because over the years, teaching in the science of law refers only to civil law oriented in Roman law (caudex, novellae, instituti, digesta) and to change the paradigm in the community that there is a positive side in every doctrine of jurisprudence belonged to any country in the world.

2. It is mandatory to amend Article 12 letter b of Law No. 20 of 2001 for the extension of the meaning of gratification by incorporating sexual elements in it so as not to cause vacuum norm.

3. The existence of social sanctions for perpetrators of corruption by performing an apology through the electronic media set by presidential decree.

\section{REFERENCES}

Anthon Freddy Susanto, 2005, Semiotika Hukum, Bandung.

Bambang Sutiyoso, 2006, Metode Penemuan Hukum, Yogyakarta: UII Press.

Bryan A Garner, 2009,Black's Law Dictionary, Ninth Edition, United States of America: Thomson Reuters.

Frédéric Bastiat, 2015, The Law, Surabaya: R.A.De.Rozarie.

Gilbert Geis dan Robert F Meier, 1977, White Collar Crime; Offensen in Business, Politics, and The Professions, New York: The Fress Press.

Hans-Georg Gadamer, 2010, Kebenaran Dan Metode, Yogyakarta: Pustaka Pelajar.

H Ansori, 2013, Gratifikasi Seksual Dalam Persona Korupsi, Surabaya: R.A.De. Rozarie.

Hikmawanto, 2012, Quo Vadis Independensi Peradilan Indonesia, Surabaya: Visipress Media

H Bagir Manan dan H Kuntana Magnar, 1997, Beberapa Masalah Hukum Tata Negara Indonesia, Bandung: Alumni. 
Tomy Michael : Corruption and Niccolo Machiavelli..... Page 263-274

Jazim Hamidi dan Mustafa Lutfi, 2010, Hukum Lembaga Kepresidenan Indonesia, Bandung: Alumni.

Moh Kusnardi dan Harmaily Ibrahim, 1986, Pengantar Hukum Tata Negara Indonesia, Jakarta: Pusat Studi HTN Fakultas Hukum UI.

Niccolo Machiavelli, 2003, Diskursus, Jogjakarta: Bentang Budaya. , 2012, The Prince, United

States: The Project Gutenberg. , 2014, Sang Pangeran, Jakarta: PT Gramedia.

Paul Scholten, 2003, Struktur Ilmu Hukum, Bandung.

Peter Mahmud Marzuki, 2008, Pengantar Ilmu Hukum, Jakarta: Kencana Prenada Media Group.

Platon, 2015, Xarmides (Tentang Keugaharian), Yogyakarta: PT Kanisius.

Soekarno, Tanpa Tahun, Indonesia Menggugat Pidato Pembelaan Bung Karno Dimuka Hakim Kolonial, Djakarta: Pradnjaparamita III.

Soerjono Soekanto, 1993, Faktor-Faktor yang Mempengaruhi Penegakan Hukum, Jakarta: RajaGrafindo Persada.

Sri Soemantri M, 1996, Penerapan Kedaulatan Rakyat Dalam Kehidupan Bernegara Berdasarkan Pancasila Dan UndangUndang Dasar 1945, Bandung: Citra Aditya Bakti.
Surya Prakash Sinha, 1993, Jurisprudence: Legal Philosophy in A Nutshell, St Paul Minnesota: West Publishing.

Thomas S Khun, 2012, Peran Paradigma Dalam Revolusi Sains, Bandung: Remaja Rosdakarya.

Tomy M Saragih, Telaah Hermeneutika Pada Perbuatan Tercela, Jurnal Konstitusi Volume II No. 1, September 2013, Malang: PKK-FH Universitas Kanjuruhan malang Kerjasama Dengan Mahkamah Konstitusi Republik Indonesia.

Tomy Michael, Pemberantasan Gratifikasi Dengan Pendidikan, Mimbar Keadilan Januari - Juni 2014, Surabaya: Laboratorium Ilmu Hukum - Fakultas Hukum Universitas 17 Agustus 1945 Surabaya.

Winarno, 2013, Paradigma Baru Pendidikan Kewarganegaraan, Jakarta: PT Bumi Aksara. 